\title{
IMPLEMENTASI KURIKULUM 2013 PADA PEMEBALAJARAN PENDIDIKAN AGAMA ISLAM DALAM PENGUATAN KARAKTER RELEGIUS SISWA
}

\author{
Subakri \\ Institut Agama Islam Negeri (IAIN) Jember \\ cakbakri@gmail.com
}

\begin{abstract}
:
The phenomenon of character education in Indonesia has existed along with the realization of the 2013 Curriculum. Character education was implemented even before the 2013 curriculum was implemented in schools. Character education is a school-based effort that helps a person or group of people care, understand, act seriously to apply ethical values. The purpose of character education is to help students develop optimal potential in various matters related to morality, citizenship, courtesy and ethics, behavior, being healthy, critical, success that will meet social norms and can be accepted in society both at home and globally. . Which one day the nation's children will become human beings with quality and noble character. With character education, students can apply character values such as religious, responsible, democratic, honest, trustworthy, leadership, fair and polite in their attitude. Character education that is integrated in the 2013 Curriculum creates the next generation who is ready to face future challenges whose goal is that students have better abilities in the ability to observe, ask (interview), reason, and communicate (present) what they get or know after receive subject matter. The 2013 curriculum which is based on character and competence lies in the core competencies of K-I 1 which includes spiritual attitudes; K-I 2 includes social attitudes; KI-3 includes knowledge, and KI-4 skills
\end{abstract}

Keywords: Kurnkulum 2013, Islamic Religious Education, Students' Religious Character

\section{ABSTRAK:}

Fenomena pendidikan karakter di Indonesia telah ada seiring dengan terealisasinya Kurikulum 2013. Pendidikan karakter diterapkan bahkan sebelum Kurikulum 2013 diterapkan di sekolah-sekolah. Pendidikan karakter adalah usaha berbasis sekolah yang membantu agar seseorang atau sekelompok orang peduli, memahami, bertindak dengan sungguh-sungguh untuk menerapkan nilai-nilai etis. Tujuan pendidikan karakter adalah 
membantu siswa-siswi mengembangkan potensi secara optimal berbagai hal terkait moral, kewargaan, sopan santun dan etika, perilaku, bersikap sehat, kritis, keberhasilan yang kelak memenuhi norma-norma social dan dapat diterima di masyarakat baik di dalam maupun secara global. Yang mana kelak anak bangsa akan menjadi manusia yang berkualitas dan berakhlak mulia. Dengan pendidikan karakter siswa-siswi dapat mengaplikasikan nilai-nilai karakter seperti relijius, tanggung jawab, demokratis, jujur, amanah, leadership, adil dan sopan santun dalam bersikap. Pendidikan karakter yang terintegrasi dalam Kurikulum 2013 menciptakan generasi penerus yang siap dalam menghadapi tantangan masa depan yang tujuannya agar siswa memiliki kemampuan yang lebih baik dalam kemampuan observasi, bertanya (wawancara), bernalar, dan mengkomunikasikan (mempresentasikan) apa yang mereka peroleh atau mereka ketahui setelah menerima materi pelajaran. Kurikulum 2013 yang berbasis karakter dan kompetensi terletak pada kompetensi inti K-I 1 yang meliputi sikap spiritual; K-I 2 meliputi sikap sosial; KI-3 meliputi pengetahuan, dan KI-4 keterampilan

Kata Kunci : Kurukulum 2013, Pendidikan Agama Islam, Karakter Relegius Siswa

\section{PENDAHULUAN}

Kata kurikulum sendiri berasal dari bahasa Latin, currere yang artinya berlari cepat dan tergesa-gesa. Pendapat lain menyebutkan kurikulum berasal dari bahasa Prancis couriar yang berarti berlari ${ }^{1}$. Ada pula yang mengartikannya sebagai "perangkat rencana dan pengaturan mengenai isi dan bahan pelajaran dalam kegiatan belajar mengajar". 2 Sedangkan dalam Kamus Umum Bahasa Indonesia, kurikulum didefinisikan sebagai susunan rencana pelajaran ${ }^{3}$.

Hakikat kurikulum pada dasarnya adalah sebagai fondasi proses belajar mengajar pada suatu institusi. Persoalannya yaitu sejauh mana kemampuan kalangan pendidik menjalankan regulasi tersebut secara efisien dan

\footnotetext{
${ }^{1}$ Mohammad, Omar, Al-Toumy Al-Syaibany. 1984. Falsafah Pendidikan Islam, Terj. Hassan Langgulung. Jakarta: Bulan Bintang, 519

${ }^{2}$ Abdul Rahman Shaleh. 2000. Pendidikan Agama dan Keagamaan, Visi, Misi, dan Aksi. Jakarta: PT. Gemawindu Pancaperkasa, 3

3 Poerwadarminta, W.J.S., 1976. Kamus Umum Bahasa Indonesia. Jakarta: Balai Pustaka, 543.
}

198 | FENOMENA, Vol.19 No. 2 Oktober 2020 
konsisten. Abdul Rahman Shaleh misalnya, berpendapat bahwa kurikulum dapat juga didefinisikan sebagai "perangkat rencana dan pengaturan mengenai isi dan bahan pelajaran dalam kegiatan belajar mengajar". Perangkat pengatur ini harus disepakati oleh semua kalangan yang terlibat langsung atau tidak langsung dalam zona pendidikan. Sehingga dalam pelaksanaannya pun memperoleh dukungan publik..

Dalam sistem pendidikan Islam, kurikulum dikenal dengan istilah 'manhaj' yang berarti 'jalan terang'. Makna tersirat dari jalan terang tersebut menurut Al-Syaibany adalah jalan yang harus dilalui oleh para pendidik dan anak-anak didik untuk mengembangkan keterampilan, pengetahuan, dan sikap mereka.

Di samping beberapa pengertian tersebut, menurut Zakiah Daradjat, seperti dikutip oleh Armai Arief, kurikulum dapat dimaknai sebagai suatu program pendidikan yang direncanakan dan dilaksanakan untuk mencapai tujuan pendidikan. ${ }^{4}$ Sedangkan Hafhi Ladjid mengutarakan pengertian lebih spesifik tentang kurikulum pendidikan Islam yaitu sebagai sarana atau alat untuk mencapai tujuan pendidikan agama Islam yang sekaligus juga arah pendidikan dalam rangka pembangunan bangsa dan manusia Indonesia seutuhnya 5 .

Lebih lanjut al-Syaibani mengemukakan, seperti yang dikutip oleh Chatib Thaha bahwa kurikulum pendidikan Islam memiliki ciri-ciri khusus, yang kesemuanya bermuara pada akhlak mulia. Secara lebih rinci corak kurikulum pendidikan yang berlandaskan Islam adalah sebagai berikut:

a. Menonjolkan tujuan agama dan akhlaqul karimah, baik dalam tujuan pengajaran, materi dan gerak pelaksanaannya.

b. Kandungan materi pendidikan mencakup aspek jasmaniah, intelektual, psikologi, dan spiritual.

c. Adanya keseimbangan antara ilmu syariah dengan ilmu-ilmu aqliyah.

d. Tidak mengesampingkan bakat dan apresiasi seni, tetapi juga tidak menghalangi perkembangan akhlak.

e. Adanya pertimbangan terhadap kondisi psikologis peserta didik. ${ }^{6}$

\footnotetext{
4 Armai Arief. 2002. Pengantar IImu dan Metodologi Penelitian Islam. Jakarta: Ciputat Press, 30.

${ }^{5}$ Hafni Ladjid. 2005. Pengembangan Kurikulum Menuju Kurikulum Berbasis Kompetensi. Jakarta: Quantum Teaching, 26.

${ }^{6}$ M. Chatib Thaha. 1996. Kapita Selekta Pendidikan. Jakarta: Pustaka Pelajar, 9.
}

FENOMENA, Vol.19 No. 2Oktober 2020 | 199 
Berangkat dari beberapa pengertian di atas dapat dipahami bahwa secara umum kurikulum merupakan suatu rancangan program pendidikan yang harus dijalani guna mencapai dan mengembangkan pengetahuan dan keterampilan, di samping juga nilai-nilai normatif.

\section{LANDASAN TEORI}

1. Jenis-jenis Kurikulum

Kurikulum dalam pelaksanaannya sangat beragam, namun bila ditinjau dari pola penerapannya kurikulum terbagi menjadi empat jenis, yakni:

a. Kurikulum Mata Pelajaran Terpisah (Separate Subject Curriculum).

Dikatakan terpisah karena kurikulum jenis ini ini menyajikan data-data pelajaran secara terpisah satu dengan yang lain. Teori ini diambil dari zaman yunani kuno yang disebut juga sebagai "The seven liberatast" yang terdiri dari Gramatika, Retorika, Logika, Aritmetika, Geometri, Astronomi, dan Musik. Intinya setiap materi pelajaran tidak memiliki keterkaitan apapun.

b. Kurikulum Korelatif (Correlated Curriculum). Kurikulum ini lebih fleksibel yakni berpandangan bahwa setiap mata pelajaran harus dihubungkan dan disusun sedemikian rupa, sehingga satu mata pelajaran memperkuat mata pelajaran yang lain. Contoh sederhana adalah mata pelajaran biologi, fisika, dan kimia yang ketiganya terhubung dalam kesatuan ilmu pengetahuan alam.

c. Kurikulum Terpadu (Integrated Curriculum). Kurikulum jenis ketiga ini cenderung mengkoordinasikan dan memadukan keseluruhan mata pelajaran dalam satu kesatuan.

d. Kurikulum Pengembangan Aktivitas (Developmental Activity Curriculum). Kurikulum jenis terakhir ini lebih rumit dibanding jenis lainnya, karena tergantung pada berbagai tingkat anak-anak. ${ }^{7}$

2. Prinsip-prinsip Pengembangan Kurikulum

Dalam konteks pengembangan kurikulum ada beberapa hal yang harus dicermati agar tidak terjadi pembuangan energi yang sia-sia tanpa hasil yang maksimal. Oemar Hamalik menyebutkan paling tidak ada 8 prinsip yang harus dijadikan patokan dalam pengembangan kurikulum, yaitu:

7 Iskandar Wiryokusumo, (et.al). 1998. Dasar-dasar Pengembangan Kurikulum. Jakarta: Bina Aksara, 20.

200 | FENOMENA, Vol.19 No.2Oktober 2020 
a. Prinsip tujuan. Pengembangan kurikulum hendaknya diarahkan untuk mencapai tujuan perbaikan pendidikan nasional.

b. Prinsip relevansi (kesesuaian). Selain memiliki tujuan untuk perbaikan pendidikan, pengembangan kurikulum juga hendaknya mempertimbangkan relevansi pengembangan tersebut dengan jenjang pendidikan siswa dan tingkat kebutuhan masyarakat terhadap perkembangan ilmu pengetahuan dan teknologi.

c. Prinsip efisiensi dan efektifitas. Menelaah secara detil mengenai efektifitas waktu, dana, dan tenaga merupakan pertimbangan lain dalam melakukan pengembangan kurikulum.

d. Prinsip fleksibilitas. Kurikulum yang tidak kaku dalam pelaksanaannya akan mudah disesuaikan, dirubah, dilengkapi, dan direvisi berdasarkan kondisi objektif pada waktu tertentu.

e. Prinsip kesinambungan. Makna kesinambungan di sini maknanya lebih kepada hubungan funsional antar bagian-bagian kurikulum. Lebih jelasnya adalah aspek-aspek, materi, dan bahan pengembangan kurikulum harus disusu secara berurutan, tidak terpisah-pisah.

f. Prinsip keseimbangan. Dalam penyusunannya, kurikulum membutuhkan keseimbangan sehingga terlihat proporsional antar unsur-unsur dalam kurikulum.

g. Prinsip keterpaduan. Terpadu berarti sebaiknya kurikulum dirancang dengan melibatkan semua pihak. Sehingga materi yang dihasilkan adalah representasi dari kebersamaan. Ketika dalam pelaksanaannya ada kekurangan maka semua pihak harus menerima sebagai sebuah masukan bagi perbaikan kurikulum berikutnya.

h. Prinsip mutu. Kualitas pendidikan yang lebih baik dan mapan merupakan harga mati bagi sebuah pengembangan kurikulum. ${ }^{8}$

3. Asas-asas Kurikulum

Mengadakan perubahan atau pengembangan kurikulum bukan hal yang mudah. Persoalannya terletak pada apa yang akan dihasilkan dari pengembangan tersebut dan apa dampak selanjutnya pasca pengembangan. Semua itu sangat erat kaitannya dengan asas-asas kurikulum. Pertimbangan pada asas bertujuan untuk menghindarkan kurikulum dari benturan terhadap sesuatu yang lebih penting. Misalnya kurikulum pendidikan agama yang

\footnotetext{
${ }^{8}$ Omar Mohammad, Al-Toumy Al-Syaibany. 1984. Falsafah Pendidikan Islam, Terj. Hassan Langgulung. Jakarta: Bulan Bintang, 31.
}

FENOMENA, Vol.19 No. 2Oktober 2020 | 201 


\section{Subakri}

hanya menekankan pada keyakinan agama tertentu akan menyebabkan disintegrasi suatu bangsa yang menganut sistem multi-agama.

Nasution berpandangan bahwa pengembangan kurikulum pada hakikatnya sangat kompleks karena banyak faktor di dalamnya yang harus dipertimbangkan. Di antara faktor tersebut salah satunya adalah asas-asas kurikulum atau disebut juga dengan determinan kurikulum, antara lain:

a. Asas filosofis, yakni mempertimbangkan sesuatu yang berkaitan dengan ideologi, falsafah hidup berbangsa dan bernegara. Tak jarang juga harus sesuai dengan karakter lembaga pendidikan.

b. Asas sosiologis, yaitu pertimbangan-pertimbangan sosio-kultural. Dengan asas ini penyusunan dan pengembangan kurikulum akan sesuai dengan kebutuhan masyarakat, kebudayaan, dan selaras dengan perkembangan ilmu pengetahuan dan teknologi.

c. Asas organisatoris, ialah yang memberikan gambaran tentang bagaimana suatu kurikulum disusun dan sejauh mana cakupannya.

d. Asas psikologis, adalah sejauh mana kesesuaian kurikulum dengan tingkat perkembangan peserta didik sehingga bahan yang akan diajarkan dapat dicerna dan dikuasai oleh anak sesuai dengan taraf perkembangannya. $^{9}$

4. Komponen-komponen Kurikulum

Mengenai komponen kurikulum para expert pendidikan berbeda pendapat terkait jumlahnya, meskipun pada dasarnya substansi dan pemahamannya hampir sama. Oemar Hamalik berpendapat bahwa komponen kurikulum terbagi menjadi tujuan, materi, metode, organisasi, dan evaluasi. Lalu Soetopo dan Soemanto misalnya, membagi komponen kurikulum menjadi lima bagian yaitu; tujuan, isi dan struktural program, organisasi dan strategi, sarana, dan evaluasi. ${ }^{1}$ Kemudian Subandijah juga membagi komponen kurikulum menjadi lima namun sedikit berbeda redaksinya, yakni tujuan, isi/materi, media (sarana dan prasarana), strategi, dan proses belajar mengajar. Sedangkan Nasution hanya membagi komponen kurikulum menjadi empat bagian, yaitu: tujuan, bahan pelajaran, proses belajar mengajar, dan penilaian. ${ }^{1}$ Selanjutnya Ralph W. Tyler dan

\footnotetext{
${ }^{9}$ Nasution, S. 1989. Kurikulum dan Pengajaran. Jakarta: Bina Aksara, 14.

1 Soetopo \& Soemanto. 1993. Pembinaan dan Pengembangan Kurikulum: Sebagai Substansi Problem Administrasi Pendidikan. Jakarta: Bumi Aksara, 38.

1 Nasution, S., 3.

202 | FENOMENA, Vol.19 No.2Oktober 2020 
Hilda Taba, seperti dikutip oleh Nana Sudjana, juga membagi komponen kurikulum menjadi empat bagian yaitu tujuan, materi pelajaran, metode, dan evaluasi. $^{1}$

2

Perbedaan dalam pembagian komponen kurikulum adalah hal yang wajar dan tidak mengubah wilayah subtantif kurikulum itu sendiri. Sebab pada dasarnya komponen-komponen kurikulum tersebut, baik secara terpisah maupun terintegrasi satu sama lainnya tetap menjadi dasar utama dalam upaya mengembangkan system pembelajaran. Untuk lebih jelas berikut akan sedikit dipaparkan tentang muatan komponen kurikulum sebagai berikut:

a. Komponen Tujuan

Seperti diketahui kurikulum adalah suatu program untuk mencapai tujuan pendidikan. Tujuan tersebut harus menjadi fokus segala aktifitas pendidikan. Berhasil tidaknya proses belajar di institusi pendidikan sangat tergantung pada seberapa maksimal pencapaian tujuan-tujuan tersebut. Dalam setiap sekolah biasanya diosialisasikan tujuan yang akan dicapai oleh sekolah yang bersangkutan, ini jelas untuk menstimulasi semua pihak di lingkungan sekolah agar pengajaran berjalan sebagaimana mestinya.

Tujuan kurikulum pada hakekatnya adalah tujuan dari setiap program pendidikan yang akan diberikan pada anak didik atau tujuan yang ingin dicapai dari proses belajar mengajar. Kurikulum sebagai suatu bagian dari proses kependidikan tidak mempunyai tujuan secara tersendiri tetapi harus merupakan penjabaran dari tujuan umum pendidikan. Berdasarkan tujuan umum pendidikan maka akan dapat dijabarkan tujuan kurikulum mulai dari tujuan lembaga, tujuan mata pelajaran sampai pada tujuan pengajaran. Dalam menentukan dan merumuskan tujuan kurikulum perlu mempertimbangkan beberapa hal diantaranya: a) Falsafah bangsa; b) strategi pembangunan; c) hakekat anak didik; dan d) ilmu pengetahuan dan teknologi. Hal ini bertujuan untuk dapat menghasilkan rumusan tujuan kurikulum yang lebih baik sehingga akan dapat mewujudkan anak didik yang memiliki kemampuan dan keperibadian yang maksimal.

Brubacher berpendapat bahwa hubungan kurikulum dengan tujuan pendidikan dilukiskan sebagai berikut: kurikulum sedemikian rupa tergantung kepada tujuan pendidikan dan sangat mengejutkan bila kita akan

1 Sudjana, Nana. 1989. Pem̌binaan dan Pengembangan Kurikulum di Sekolah. Bandung: Sinar Baru, 53.

FENOMENA, Vol.19 No. 2Oktober 2020 | 203 
mengetahui bahwa mempelajari kurikulum pada hakikatnya sama dengan mencapai tujuan pendidikan itu sendiri. Betapa pentingnya kurikulum sehingga dapat dikatakan bahwa kurikulum merupakan tujuan pendidikan atau nilai-nilai yang termaktub dalam bentuk yang luas. ${ }^{1}$ Agar tujuan tersebut terwujud maka harus dirumuskan secara khusus. Perumusan ini dipusatkan pada perubahan tingkah laku siswa dan kemudian mendudukan tujuan itu dalam kerangka fungsional.

b. Komponen Isi / Materi

Materi kurikulum adalah isi kurikulum itu sendiri. Undang-undang Pendidikan Bab IX pasal 39 tentang Sistem Pendidikan Nasional telah menetapkan bahwa "Isi kurikulum merupakan bahan kajian dan pelajaran untuk mencapai tujuan penyelenggaraan satuan pendidikan yang bersangkutan dalam rangka upaya pencapaian tujuan pendidikan nasional." Maka sesuai dengan rumusan tersebutm menurut Oemar Hamalik, isi kurikulum dikembangkan dan disusun berdasarkan prinsip-prinsip sebagai berikut:

1) Materi kurikulum berupa bahan pembelajaran yang terdiri dari bahan kajian atau topik-topik pelajaran yang dapat dikaji oleh siswa dalam proses belajar dan pembelajaran.

2) Materi kurikulum mengacu pada pencapaian tujuan masing-masing satuan pendidikan.

3) Materi kurikulum diarahkan untuk mencapai tujuan pendidikan nasional.

Selanjutnya, isi kurikulum tentu merupakan bagian yang berisi pengetahuan, informasi, data, aktifitas dan pengalaman-pengalaman yang membentuk kurikulum. Bagian ini biasa disebut mata pelajaran Isi kurikulum juga berkenaan dengan pengetahuan ilmiah dan pengalaman belajar yang harus diberikan kepada siswa untuk dapat mencapai tujuan pendidikan. Ada beberapa kriteria yang digunakan dalam memilih mata pelajaran sebagai isi kurikulum antara lain: ${ }^{1}$

1) Pentingnya mata pelajaran dalam kerangka pengetahuan keilmuan. artinya mata pelajaran yang di pilih sebagai kurikulum harus jelas

\footnotetext{
1 John. S. Bubacher, 1962. Modern Philosophy of Education (New Jersey: Engelwood Company, p. 238.

${ }^{1}$ Nana Sudjana. 1989. Pembinaan dan Pengembangan Kurikulum di Sekolah. Bandung: Sinar Baru, 34.
}

204 | FENOMENA, Vol.19 No.2Oktober 2020 
kedudukannya dalam kontek pengetahuan ilmiah, sehingga jelas apa yang harus dipelajari (ontologi), jelas bagaimana cara mempelajari/metodenya (epistemologi) dan jelas manfaatnya bagi anak didik/manusia (aksiologi).

2) Mata pelajaran harus tahan uji. Mata pelajaran tersebut dapat bertahan dalam kurun waktu tertentu.

3) Kegunaan bagi anak didik dan masyarakat pada umumnya, artinya mata pelajaran itu bermanfaat dan memiliki kontribusi yang tinggi terhadap perkembangan anak didik dan sesuai dengan harapan masyarakat.

Isi kurikulum disusun dalam bentuk program pendidikan yang nantinya dijabarkan dan dijelaskan melalui pengajaran/ pengalaman anak didik. Kurikulum bukan hanya pengetahuan ilmiah yang terorganisir dalam bentuk mata pelajaran saja tetapi juga kegiatan dan pengalaman sebagai bagian yang integral dari proses pendidikan serta pengajaran di sekolah.

Dalam kaitannya dengan kurikulum pada dasarnya para pemikir pendidikan Islam mempunyai pendapat bahwa ilmu pengetahuan yang dikategorikan sebagai materi pelajaran hams mencerminkan idealitas Qur'an yang tidak memilah-milah jenis disiplin ilmu secara taksonomis dikotomik; menjadikan ilmu agama terpisah dari ilmu duniawi, yang di Indonesia lazim disebut pengetahuan umum. Senada dengan ini pandangan Al-Farabi, Ibn Sina dan para ahli didik Ikhwannus Shofa menegaskan bahwa kesempurnaan ajaran agama itu tidak akan tercapai kecuali dengan menserasikan antara agama dan ilmu pengetahuan. Oleh karena itu materi pelajaran yang tersusun dalam kurikulum pendidikan Islam itu nilainya diukur berdasarkan: keserasian antara iman (agama) dan ilmu pengetahuan (umum). Sebab keduanya terdapat hubungan fungsional yang bersifat saling memperkokoh dan saling mempengaruhi, sehingga orang yang makin bertambah ilmunya maka semakin kuat imannya dan semakin terdorong pula untuk menambah ilmu pengetahuan. Manusia seperti inilah yang akan mendapatkan derajat yang tinggi.

Berdasarkan ayat ini dapat dikatakan bahwa isi kurikulum pendidikan Islam itu dirancang berdasarkan nash $\mathrm{Al}$ Qur'an yang bertujuan agar manusia mendapat kesejahteraan (memperoleh derajat yang tinggi), yang dengan kedudukannya ia mendapatkan kemuliaan di tengah kehidupan manusia dan semakin dekat kepada Khaliqnya.

FENOMENA, Vol.19 No. 2Oktober 2020 | 205 
Disamping itu diisyaratkan tentang sifat isi kurikulum (materi) yang diberikan ketika Rasulullah mengajarkan dalam madrasahnya, antara lain:

1) Bukan Rekayasa Manusia

Materi yang sifatnya seperti ini dapat melahirkan kemuliaan, ketenangan, memprioritaskan kemaslahatan dan keselamatan, tidak di pengaruhi oleh faktor kejiwaan dari dalam/peristiwa luar bersifat konsisten.

2) Mudah dan Toleran

Materi yang dibawa sebagai Ilmu Rabbani sangat realistis, dapat diterapkan bagi individu ataupun masyarakat agar setiap individu mencapai derajat kesempurnaan sehingga tercipta masyarakat yang mampu merealisasikan kemaslahatan yang di kehendaki Allah.

3) Terang dan Jelas

Ilmu yang disampaikan oleh Rasulullah SAW tidak ada keraguan kenisbian atau kerancuan. Sebab itu Rasulullah SAW mengisyaratkan petunjuk dari Ilmu Allah laksana air hujan dalam kejernihannya dan keluasan areal yang dituruninya serta manfaatnya. Al-Ghazali berpendapat tentang kejelasan Ilmu dalam Al-Qur'an: Ibarat makanan yang bermanfaat bagi setiap orang.

4) Menjelma dalam sosok manusia

Ilmu tidak hanya tertulis namun tertanam dalam perbuatan, oleh karena itu "suri tauladan" mempunyai esensi tersendiri dalam Islam. Maka tabiat ilmu atau materi dalam agama Islam hams direalisasikan.

5) Utuh dan saling berkaitan

Ajaran Islam itu merupakan satu kesatuan yang tidak dapat dipisahkan, seperti yang di sabdakan oleh Rasulullah bahwa: "Iman seorang belum sempurna jika melihat tetangganya lapar sedang la dalam keadaan kenyang"

6) Luas dan Menyebar

Materi ajaran Islam merupakan ajaran bagi seluruh ummat manusia oleh sebab itu hams selalu disebar luaskan, sehingga Rasul banyak memotivasi akan perbuatan ini.

Berdasarkan sifat-sifat materi sebagai isi kurikulum yang diajarkan oleh Rasulullah tersebut di atas maka pendekatan Islam dalam merumuskan kurikulumnya menekankan wahyu (yang terpelihara dalam Al-Qur'an dan Sunnah) sebagai sumber Ilmu di samping Ilmu yang dicari oleh akal.

c. Komponen Strategi

206 | FENOMENA, Vol.19 No. 2 Oktober 2020 
Strategi disebut juga sebagai metode yang digunakan untuk menyampaikan materi pelajaran dalam upaya mencapai tujuan kurikulum. Suatu metode dikatakan berhasil bila kegiatan guru dan siswa terlaksana dengan baik dalam proses belajar mengajar. Metode dilaksanakan melalui prosedur tertentu.

Metode atau strategi pembelajaran menempati fungsi yang penting dalam kurikulum, karena memuat hal-hal yang perlu dikerjakan oleh guru dan siswa. Karenanya penyusunan metode diupayakan berdasarkan analisa tugas yang mengacu pada tujuan kurikulum dan prilaku awal siswa. Dalam hubungannya dengan hal ini, menurut Oemar Hamalik ada tiga alternatif pendekatan yang dapat digunakan, yaitu: ${ }^{1}$

1) Pendekatan yang berpusat pada mata pelajaran, di mana materi pelajarn menjadi inti komunikasi guru dan murid.

2) Pendekatan yang berpusat pada siswa. Pembelajaran dilaksanakan berdasarkan kebutuhan, minat, dan kemampuan siswa.

3) Pendekatan yang berorientasi pada kehidupan masyarakat. Pendekatan ini bertujuan mengintegrasikan sekolah dan masyarakat untuk mengetahui cara memperbaiki kehidupan masyarakat.

\section{d. Komponen Evaluasi}

Evaluasi pada dasarnya adalah proses penentuan nilai sesuatu berdasarkan kriteria tertentu. Dalam proses evaluasi terdapat beberapa komponen, yaitu mengumpulkan data/informasi yang diperlukan sebagai dasar dalam menentukan nilai sesuatu yang menjadi obyek evaluasi.

Menurut Stufflebeam, ada tiga hal penting yang tercakup dalam proses evaluasi, (a) menetapkan suatu nilai, (b) adanya suatu kriteria, (c) adanya deskripsi program sebagai obyek penilaian. ${ }^{1}$

Komponen lain yang dapat menunjang keberhasilan evaluasi kurikulum yaitu pertimbangan. Pertimbangan merupakan hasil yang sangat penting dalam proses evaluasi. Pertimbangan tersebut diharapkan tepat jika informasi yang diperoleh juga tepat. Oleh karena itu, pengumpulan informasi harus didasarkan pada rencana pertimbangan yang telah ditetapkan.

Penelitiaan ini merupakan penelitian pustaka. Membahas tentang implementasi kurikulum 2013 pada materi pembelajaran PAI.

\footnotetext{
${ }^{1}$ Oemar Hamalik. 1995. Kurikufum dan Pembelajaran. Jakarta: Bumi Aksara, 22.

${ }^{1}$ Oemar Hamalik, 15. 
Subakri

\section{TEMUAN HASIL PENELITIAN DAN PEMBAHASAN}

Perubahan adalah keniscayaan yang tidak dapat dihindari oleh siapapun oleh apapun dan dimanapun, sebagai suatu yang berbentuk sunnatullah dalam kehidupan didunia, termasuk dunia pendidikan. Sehingga inovasi senantiasa merupakan sesuatu yang harus dilakukan. Perubahan yang inovatif yaitu perubahan yang mengarah kepada hal-hal yang lebih baik lagi. Konsep Ibnu Khaldun seorang filosof muslim bisa dijadikan pegangan bahwa sesuatu pasti berubah kecuali perubahan itu sendiri.

Dalam konteks kurikulum banyak kritik yang sumir dan cenderung tendensius, melihat perubahan yang terjadi. Seakan kurikulum berubah karena ada perubahan menteri pendidikan, tentu kondisi yang terjadi dimasyarakat ini memiliki implikasi yang kurang efektif bagi penerimaan suatu perubahan yang terjadi pada kurikulum. Bahkan nada yang berbau putus asa sering terdengar menjadi keluhan pada penerimaan terhadap perubahan kurikulum pendidikan Indonesia. Walaupun kemungkinan kebenaran dari isu-isu sumbang yang berkembang dimasyarakat masih butuh kajian-kajian yang dalam dari pespektif ilmiah rasional. Namun demikian tidak dipungkiri terjadi seakan-akan menjadi kebetulan bahwa ketika terjadi pergantian menteri maka terjadi pergantian kurikulum. Bahkan cenderung kurikulum yang sebelumnya belum difahami benar oleh sebagian masyarakat sudah berubah.

Demikian juga perubahan yang terjadi dalam kurikulum baru yang lebih akrab dengan K13., kurikulum ini dibangun dan diterapkan pada tahun ajaran 2014-2015 secara serentak diseluruh Indonesia. Meski ada beberapa kelas yang masih akan menggunakan kurikulum lama. Kehadiranya tentau menimbulkan reaksi baik positif maupun negative. Namun bagaimanapun juga kurikulum ini harus dilaksanakan. Dengan tentunya memperhatikan beberapa keluhan-keluhan yang muncul menemani munculnya kurikulum 2013 atau K13. Sehingga ada ungkapan bahwa kurikulum K13 ini sebagai life curiculum, atau kurikulum hidup.

Pengkajian mengenai pendidikan formal, terutama yang terkait dengan proses belajar mengajar tidak bisa dipisahkan dari persoalan kurikulum. Kurikulum menjadi semacam barometer tersendiri berhasil tidaknya proses pengajaran. Yang perlu digarisbawahi adalah kurikulum tidak hanya identik dengan satuan mata pelajaran saja. Menurut Hilda Taba, seperti dikutip oleh

Nasution, kurikulum tidak boleh didefinisikan terlalu luas namun juga tidak

208 | FENOMENA, Vol.19 No. 2 Oktober 2020 
terlalu sempit. (Nasution, 1995) Semua aspek yang terkait dengan pendidikan seperti metode belajar, sasaran-sasaran pembelajaran, juga termasuk dalam lingkup kurikulum. Dengan merujuk kepada 'regulasi akademik' tersebut diharapkan proses pendidikan akan berjalan secara sistematis dan memiliki orientasi yang jelas. Sebab arah pendidikan di samping sebagai media peningkatan penguasaan pengetahuan, kemampuan, dan keterampilan, juga merupakan sarana pengembangan nilai-nilai normatif dalam rangka membentuk jati diri peserta didik.

Kecenderungan perluasan makna dalam mengartikan kurikulum tak lepas dari semakin berkembangnya fenomena pendidikan dengan segala sistem yang dianut suatu lembaga pendidikan. Dengan merujuk kepada 'rencana belajar' tersebut diasumsikan proses pendidikan akan berjalan secara sistematis dan teratur serta memiliki orientasi yang jelas yakni mencerdaskan kehidupan bangsa. Sebab pada dasarnya tujuan pendidikan adalah peningkatan penguasaan pengetahuan, kemampuan, keterampilan, dan pengembangan nilai-nilai normatif dalam rangka membentuk jati diri peserta didik.(Sukmadinata, 2004) Artinya di samping prasarana yang memadai seperti tempat belajar, instrumen belajar, dan pendidik, kurikulum tentunya memiliki peran strategis. Hal ini sekaligus juga mengindikasikan bahwa dalam pencapaian sebuah tujuan membutuhkan integritas yang tertata dengan baik antar komponen-komponen pendukung.

Untuk mengembangkan kurikulum, tentu dibutuhkan prinsip-prinsip praktis dan integral yang dapat memberikan petunjuk pada permasalahan dan pengambilan keputusan tentang tujuan dan langkah yang diperlukan untuk mencapai pendidikan yang efektif dan komprehensif. Menurut pendapat Jusuf Amir, setidaknya ada tiga hal yang harus diperhatikan dalam pengembangan kurikulum, yaitu:( Amir Feizal, 1995) pertama, setiap ilmu memiliki nilai dasar; kedua, proses pembelajaran itu melatih perkembangan dan intelektual; dan ketiga, pendidikan harus memungkinkan dapat dipergunakan atau dapat diaplikasikan dalam kehidupan sehari-hari. Dengan begitu, maka manfaat dari pengembangan kurikulum tersebut tidak hanya bagi kalangan pendidikan tapi juga mengakomodir kebutuhan mayarakat. Selain itu menurut S. Nasution, dalam penyusunan dan perencanaan kurikulum sangat membutuhkan pertimbangan psikologis di samping pertimbangan akademis sebagai landasan dasar. Sebab dalam penerapannya kurikulum akan terus berhadapan dengan pribadi yang berbeda-beda.

FENOMENA, Vol.19 No. 2Oktober 2020 | 209 
Salah satu prinsip pengembangan kurikulum yang rasional adalah prinsip fleksibilitas,(Subandijah, 1993) yang intinya menjelaskan bahwa kurikulum tidaklah kaku. Dalam tataran praktis dapat diartikan bahwa dalam penyelenggaraan proses pendidikan harus diperhatikan pula perbedaan yang ada. Disinilah maka kurikulum 2013 atau K13 dihadirkan dalam rangka menjawab persoalan-persoalan yang selama ini dianggap menjadi persoalan yang masih harus diselesaikan dalam dunia pendidikan.

Setidaknya ada beberapa perubahan yang muncul dalam kurikulum 2013 dan diharapkan menjadi sesuatu yang menyelesaikan atas kekurangan dalam kurikulum sebelumnya. Artinya kurikulum sebelumnya tidak semuanya tidak dipakai, ada hal-hal yang masih menjadi bagian yang dipakai didalamnya karena prinsipnya adalah memperbaiki bukan mengganti. Dari paradigma kurikulum 2013 yang bertujuan untuk memperbaiki maka kurikulum-kurikulum sebelumnya dipakai seperti kurikulum KBK, KTSP. Sehingga muncul proses pendidikan dan pembelajaran yang lebih baik dan diharapkan lebih sempurna.

Elemen-elemen perubahan yang ada di Kurikulum 2013 terdiri dari : 1)Standart Kompetensi Lulusan (SKL), 2) Standart Proses, 3) Strandart Isi, 4) Standart penilaian Jemen-elemen perubahan diatas akan sangat menarik jika dikaji secara komperhensif. Namun pada hakikatnya elemen-elemen perubahan yang ditawarkan oleh Kurikulum 2013 dalam kacamata pemikiran penulis memberikan suatu yang lebih komperhensif dalam implementasi di dalam proses pembelajaran. K Kian yang lebih menarik lagi dari kurikulum 2013 ini adalah munculnya peraturan perundang-undangan yang melingkupi. Yang disalammnya juga mencantumkan Rencana Pelaksanaan Pembelajaran.

Bagi pembelajaran pendidikan agama Islam, implementasi kurikulum 2013 memiliki pola pelaksanaan yang berbeda dengan mata pelajaran yang lain. Dimana proses integrasi keilmuan tidak lagi dijalankan, karena pendidikan Agama Islam dalam konteks pembelajaran tidak membutuhkan integrasi. Bahkan tematik yang diharuskan dalam proses pembelajaran tidak dilakukan karena setiap mata pelajaran yang dilakukan dalam konteks pembelajaran pendidikan agama Islam unsure-unsur kompetensi yang diajarkan sudah mengandung tema-tema yang relevan.

\section{KESIMPULAN}


Kurikulum 2013 yang berbasis karakter dan kompetensi boleh jadi mendasari pengembangan kemampuan-kemampuan lain. Penguasaan ilmu pengetahuan, dan keahlian tertentu dalam suatu pekerjaan, kemampuan memecahkan masalah dalam kehidupan sehari-hari, serta pengembangan aspek-aspek kepribadian dapat dilakukan secara optimal berdasarkan standard kompetensi tertentu. Implementasi pendidikan karakter pada Kurikulum 2013 adalah suatu sistem yang telah terintegrasi dengan baik, yang mana aspek karakter menjadi pokok orientasi pada Kurikulum 2013. Dan tujuan dari Kurikulum 2013 adalah terwujudnya akhlak mulia yang memiliki nilai-nilai sesuai dengan muatan nilai pada pendidikan karakter, yaitu produktif, kreatif, inovatif, berpengetahuan. Cakupan nilai meliputi aspek sosial dan spiritual.

Muatan nilai-nilai karakter yang tertanam pada diri peserta didik, baik pada saat kegiatan pembelajaran maupun saat kegiatan sekolah antara lain: seperti tanggung jawab (responsibility), sopan santun, disiplin (discipline), dan memiliki jiwa spiritual yang tinggi (religious), jujur, kewarganegaraan (citizenship), percaya diri (confident) telah menjadi karakter yang terbentuk dalam diri siswa-siswi. Kegiatan penunjang atau program-program pelaksanaan pendidikan karakter di sekolah pun terlaksana dengan baik, dengan beberapa faktor pendukung dari mulai pimpinan sampai seluruh stake holder di sekolah, serta sarana dan prasarana yang menunjang kebutuhan siswa untuk menerapkan life skill sesuai dengan potensi yang dimiliki.

\section{Daftar Pustaka}

Al-Munawar, Said Agil Husein. 2003. Aktualisasi Nilai-nilai Qur'ani dalam Sistem Pendidikan Islam. Jakarta: Ciputat Pers.

Arief, Armai. 2002. Pengantar Ilmu dan Metodologi Penelitian Islam. Jakarta: Ciputat Press.

Bubacher, John. S. 1962. Modern Philosophy of Education (New Jersey: Engelwood Company.

Feisal, Jusuf Amir. 1995. Reorientasi Pendidikan Islam. Jakarta: Gema Insani Press.

Hamalik, Oemar. 1995. Kurikulum dan Pembelajaran. Jakarta: Bumi Aksara.

Hasan, Muhammad Tholhah. 2005. Islam Dalam Perspektif Sosio Kultural. Jakarta: Lantabora Press.

FENOMENA, Vol.19 No. 2Oktober 2020 | 211 
Subakri

Ibrahim, R. 1991. Materi Pokok Pengembangan Inovasi dan Kurikulum (Jakarta: Universitas Terbuka, Departemen Pendidikan dan Kebudayaan.

Ladjid, Hafni. 2005. Pengembangan Kurikulum Menuju Kurikulum Berbasis Kompetensi. Jakarta: Quantum Teaching.

Mohammad, Omar, Al-Toumy Al-Syaibany. 1984. Falsafah Pendidikan Islam, Terj. Hassan Langgulung. Jakarta: Bulan Bintang.

M. Fadlillah, 2014, Implementasi Kurikulum 2013 Dalam Pembelajaran, Yogjakarta, Ar-Ruzz Media.

Nasution, S. 1989. Kurikulum dan Pengajaran. Jakarta: Bina Aksara.

Nasution, S. 1993. Pengembangan Kurikulum. Bandung: PT. Citra Aditya Bakti.

Nasution, S. 1995. Asas-asas Kurikulum. Jakarta: Bumi Aksara.

Nata, Abuddin. 1997. Filsafat Pendidikan Islam. Jakarta: Logos Wacana Ilmu.

Nata, Abuddin. 2005, Pendidikan dalan Perspektif Hadits. Jakarta: UIN Jakarta Press.

Poerwadarminta, W.J.S., 1976. Kamus Umum Bahasa Indonesia. Jakarta: Balai Pustaka.

Ragan, William B., 1960. Modern Elementary Curriculum (Revised Edition). United States of America: Rinehart and Winston.

Rahim, Husni. 2001. Arah Baru Pendidikan Islam di Indonesia. Jakarta: Logos Wacana Ilmu.

Rahman, Afzalur. 2000. Al-Qur'an Sumber Ilmu Pengetahuan, Terj. H. M. Arifin. Jakarta: Rineka Cipta.

Shaleh, Abdul Rahman. 2000. Pendidikan Agama dan Keagamaan, Visi, Misi, dan Aksi. Jakarta: PT. Gemawindu Pancaperkasa.

Soetopo \& Soemanto. 1993. Pembinaan dan Pengembangan Kurikulum: Sebagai Substansi Problem Administrasi Pendidikan. Jakarta: Bumi Aksara.

Subandijah. 1993. Pengembangan dan Inovasi Kurikulum. Jakarta: RajaGrafindo Persada.

Sudjana, Nana. 1989. Pembinaan dan Pengembangan Kurikulum di Sekolah. Bandung: Sinar Baru.

Sukmadinata, Nana Syaodih. 2004. Landasan Psikologi Proses Pendidikan. Bandung: PT. Remaja Rosdakarya.

Sukmadinata, Nana Syaodih. 2010. Metode Penelitian Pendidikan. Bandung: Remaja Rosdakarya.

Thaha, H.M. Chatib. 1996. Kapita Selekta Pendidikan. Jakarta: Pustaka Pelajar.

212 | FENOMENA, Vol.19 No. 2 Oktober 2020 
Implementasi Kurikulum 2013

Wiryokusumo, Iskandar, (et.al). 1998. Dasar-dasar Pengembangan Kurikulum. Jakarta: Bina Aksara.

FENOMENA, Vol.19 No. 2Oktober 2020 | 213 